\title{
POVEZANOST SAMOPROCIJENJENIH SIMPTOMA ADHD-A S AGRESIVNIM PONAŠANJEM I SUDJELOVANJEM U VRŠNJAČKOM NASILJU UČENIKA OSNOVNOŠKOLSKE DOBI $^{1}$
}

\author{
TENA VELKI I KSENIJA ROMSTEIN
}

Sveučilište J. J. Strossmayera u Osijeku, Fakultet za odgojne i obrazovne znanosti u Osijeku, Cara Hadrijana 10, 31000 Osijek, kromstein@foozos.hr

Primljeno: 14.3.2016.

Izvorni znanstveni rad

Prihvaćeno: 5.9.2016.

UDK: $159.952 .6-053.2$

Sažetak: Brojna istraživanja potvrdila su povezanost ADHD-a s vršnjačkim nasiljem i agresivnim ponašanjem. Cilj istraživanja bio je provjeriti povezanost različitih samoprocijenjenih simptoma ADHD-a (hiperaktivnost, impulzivnost i nepažnja) s različitim aspektima vršnjačkog nasilja (tjelesno, verbalno i elektroničko) $i$ agresivnim ponašanjem (reaktivna i proaktivna agresija). U istraživanju je sudjelovao 501 učenik 4., 6. i 8. razreda, 50,7\% dječaka i 49,3\% djevojčica prosječne dobi $M=12,72$ (sd=1,62). Učenici su tijekom jednog školskog sata ispunili Upitnik o nasilju među školskom djecom (Velki i Kuterovac Jagodić, 2012), Upitnik reaktivno-proaktivne agresije (RPQ; Raine i sur., 2006) i Skalu hiperaktivnosti-impulzivnosti-pažnje (Vulić-Prtorić, 2006). Provedena je korelacijska analiza (Pearsonov koeficijent korelacije), a značajnost razlika u korelacijama testirana je Fisherovim z testom. Dobivene su statističke značajne povezanosti sve tri mjere vršnjačkog nasilja, verbalno, tjelesno i elektroničko sa sve tri skupine simptoma ADHD-a, impulzivnost, hiperaktivnost, nepažnja $(r=0,151-0,411, p<0,01)$, kao i povezanost svih simptoma ADHD-a s reaktivnom i proaktivnom agresijom $(r=0,318-0,486, p<0,01)$. Razlike u značajnosti korelacija ovisno o simptomu ADHD-a dobivene su za povezanosti s verbalnim vršnjačkim nasiljem i proaktivnom agresijom, gdje je dobivena jača povezanost impulzivnosti $i$ verbalnog vršnjačkog nasilja u odnosu na povezanost s hiperaktivnosti $(z=2,20, p<0,05) i$ u odnosu na povezanost s nepažnjom $(z=1,95, p<0,05)$ te jača povezanost impulzivnosti i proaktivne agresije u odnosu na povezanost $s$ hiperaktivnosti $(z=2,42, p<0,05)$ i u odnosu na povezanost s nepažnjom $(z=2,63, p<0,01)$. Razlike u povezanosti vršnjačkog nasilja i agresivnog ponašanja sa simptomima nepažnje i hiperaktivnosti nije bilo. Rezultati su potvrdili prijašnje nalaze koji govori u prilog o povezanosti ADHD-a s vršnjačkim nasiljem i agresivnim ponašanjem, a posebice da je ta povezanost jača kada se radi o impulzivnosti. Iz navedenog možemo zaključiti da simptomi impulzivnosti predstavljaju rizik za razvoj vršnjačkog nasilja i agresivnog ponašanja, te da bi bilo dobro djecu koja pokazuju simptome impulzivnosti uključiti u prevencijske programe za sprječavanje razvoja vršnjačkog nasilja i agresije.

Ključne riječi: agresivnost, vršnjačka interakcija, vršnjačko nasilje, hiperaktivnost, impulzivnost, nepažnja

\section{Uvod}

Kada se u odgojno-obrazovnom kontekstu govori o ADHD-u, tada se najčešće ističe motorički nemir kao glavni problem u savladavanju nastavnih sadržaja. Iz motoričkog nemira, prema takvoj simplističkoj interpretaciji, proizlazi nemogućnost praćenja nastave i posljedično, ispodprosječno akademsko postignuće te problemi u odnosima s okolinom. Propitujući ispodprosječna akademska postignuća učenika s ADHD-om, Swanson (2012) utvrđuje kako postupci i stavovi učitelja u kojima dominira izostanak znanja o kliničkoj slici ADHD-a i izostanak vještina vezanih uz razvojno primjerene postupke, značajno doprinosi problemu djetetova lošeg općeg funkcioniranja u neposrednom okruženju. Propitujući mogućnost uključivanja djece s ADHD-om predškolske dobi u dječje vrtiće u Republici Hrvatskoj, Loborec i Bouillet (2012) pro-

1 Rezultati ovog rada dio su šireg projekta „Konstrukcija interakcijskog modela ADHD-a: identifikacija čimbenika prilagodbe na školsko okruženje učenika osnovnoškolske dobi suspektnih na ADHD“ odobrenog od strane Sveučilišta J.J. Strossmayera u Osijeku 2015. godine. 
nalaze kako odgojitelji sami sebe procjenjuju kao nekompetentnima za rad s djecom s ADHD-om $\mathrm{u}$ smislu nepoznavanja mogućih didaktičko-metodičkih postupaka kojima bi se facilitirala uključenost te djece u svakodnevne aktivnosti u odgojnim skupinama. Slično tomu, Romstein (2011) pronalazi kako učitelji ne znaju razlikovati razvojno očekivana ponašanja od onih koji bi ukazivali na odstupanje u odnosu na djetetovu kronološku dob. Tako, primjerice, učitelji uobičajenim ponašanjima drže djetetovu intenzivnu motoričku aktivnost, kratkotrajnu pozornost, nemogućnost iznošenja aktivnosti do kraja, čitanje "napamet" i govorenje "unaprijed" (brzanje) te odupiranje odraslima (izvanjskom autoritetu), što ujedno predstavljaju i dijagnostičke kriterije za ADHD. Propitujući ADHD u kontekstu odgoja i obrazovanja, Webb, Goerss i Olenchak (2010) ističu kako je on odraz socijalnih očekivanja i djetetove percepcije relevantnosti određene aktivnosti/ zadatka, zbog čega prilikom utvrđivanja postojanja ADHD-a u obzir treba uzeti i izvanjske čimbenike poput normativnosti nastavnog procesa i emocija koje se javljaju u dinamici interpersonalnih odnosa unutar pojedinog razreda. Iako je za učeničko postignuće bitno da učitelji mogu prepoznati ponašanja (kakvo je neko ponašanje, što je uzrok ponašanju), važnije je da znaju pružiti djetetu pravovremenu i primjerenu podršku (kako pomoći djetetu). Takvim, individualnim pristupom se djetetu omogućuje usvajanje i prakticiranje primjerenih strategija rješavanja problema u odnosima s okolinom, pa se može govoriti i o prevencijskim učincima individualnog rada. To je posebice bitno kod djece koja nemaju formalno utvrđeno postojanje ADHD-a ali u pojedinim aspektima svakodnevnog funkcioniranja manifestiraju njegovu kliničku sliku, o čemu se u postojećoj pedagoškoj praksi ne vodi dovoljno računa.

Zbog složene problematike ADHD-a, u kojoj značajnu ulogu imaju i socijalna očekivanja, sve se češće pojavljuju istraživanja koja govore o važnosti socijalnih vještina u smislu uspostavljanja funkcionalnih odnosa s okruženjem, točnije osobama iz neposrednog okruženja. Tako Žic Ralić i Šifner (2014) pronalaze kako djeca i mladi s ADHD-om ćešće sudjeluju u vršnjačkom nasilju i to češće kao žrtve, nego što su to njihovi vršnjaci. Uzroke tomu vide u dječjoj nemogućnosti adekvatne interpretacije socijalnih situacija zbog čega bi učitelji trebali mijenjati socijalno okruženje u smjeru podržavanja kvalitetnih vršnjačkih odnosa i savladavanja strategija adekvatnog reagiranja u vršnjačkim konfliktima (ibid.). Nadalje, Opić i Kudek Mirošević (2011) pronalaze kako učitelji na jednak način pristupaju učenicima koji imaju ADHD i onima koji ga nemaju, što govori o nepoznavanju specifičnosti funkcioniranja te djece kao i izostanak pedagoškog planiranja strategija poučavanja, što je svakako potrebno ako se govori o inklzivnom odgoju i obrazovanju. To ukazuje kako odgojitelji i učitelji trebaju tražiti dodatne informacije o mogućnostima iznošenja razvojne primjerenosti u okvirima različitih teorija poučavanja. Čini se kako je slična situacija i u drugim zemljama. Umjesto mijenjanja socijanih situacija i refleksije o osobnom iskustvu, Mikami i Normand (2015) ističu kako se u Sjedinjenim Američkim Državama naglasak u radu s djecom stavlja na promjenu ponašanja neovisno o vlastitoj percepciji situacije u kojoj se dijete našlo te ih se vrlo malo osnažuje za učinkovito snalaženje u promjenjivim međuljudskim odnosima. Prema njihovu tumačenju, djeca s ADHD-om, jednako kao i sva ostala djeca, imaju vlastitu percepciju međuljudskih odnosa što se reflektira i na odnose s vršnjacima zbog čega bi bilo potrebno saznati dječje perspektive o konfliktnim situacijama (Mikami i Normand, 2015). Odnosno, vršnjački odnosi su temeljeni na recipročnim akcijama svih sudionika pri čemu osobna percepcija određene situacije ima važnu ulogu. Što se tiče percepcije kvalitete odnosa s okolinom, istraživanja su pokazala kao je ona snižena, tj. djeca s ADHD-om su nezadovoljna odnosima s drugima, češće od ostale djece se osjećaju odbačenima te posljedično pokazuju simptome depresije češće od djece koja nemaju ADHD (Houck i sur., 2012; Paap i sur., 2013, McQuade i Hoza, 2015). To ukazuje kako je ADHD razvojna teškoća složene fenomenologije u smislu postojanja interakcije različitih čimbenika, pri čemu se ne može točno odrediti “najkritičnija" točka koji bi se rehabilitacijskim postupcima reducirala ili otklonila, već se isprepliću unutarnji i vanjski čimbenici koji rezultiraju problemima u odnosima s okolinom. U odnosima s vršnjacima ti problemi su različiti, a najčešće se govori o pojavi agresivnog ponašanja i vršnjačkog nasilja ${ }^{2}$ te vršnjačkog odbacivanja. To se u prvome redu odnosi na povezanost impulzivnosti s nasilnim i agresivnim ponašanjem prema vršnjacima (McQuade i Hoza, 2015) i povezanost slabe emocionalne regulacije $i$ 
statusa u grupi vršnjaka (Barkley, 2015). Za Schwencka i sur. (2011) najveći problem u odnosima s vršnjacima je niža razina empatije koju obrazlažu nedostatkom informacija/uvida u emocionalna stanja druge djece i to na način da se (zbog organske podloge) informacije o odnosima na mikro-razini ustrojavaju na specifičan način, što u kombinaciji s nepovoljnim utjecajima okoline rezultira nižom razinom osjetljivosti za druge. Nadalje Evans i sur. (2015) utvrđuju da djeca s ADHD-om češće od ostale djece manifestiraju agresivna i nasilnička ponašanja, no ističu da se kod njih radi o reaktivnoj agresiji, koja posljedično vodi u vršnjačko isključivanje. Slično njima, McQuade i Hoza (2015) napominju kako je vrlo vjerojatnije da će djeca s ADHD-om biti zlostavljana od strane vršnjaka, upravo zbog sniženih socijalnih vještina i nemogućnosti samoregulacije u odnosima s okolinom, no učitelji često ne percipiraju djecu s ADHD-om kao žrtve. Istražujući anticipacijske stavove prema djeci s ADHD-om Ercan i sur. (2014) pronalaze kako učitelji očekuju da djeca s ADHD-om češće od ostale djece budu agresivna i izazivaju konflikte. Zbog toga djeca s ADHD-om lako postaju "dežurni krivci" za sve probleme u razredu. S obzirom na to da se agresivnost i nasilničko ponašanje tumače kao odraz djetetovog osobnog izbora (a ne interakcijskih procesa u odgojno-obrazovnom okruženju), djeci se pristupa korekcijski s jakom penološkom komponentom čime se djeci onemogućuje građenje pozitivne slike o sebi. Štoviše, Houck i sur. (2012) tvrde kako većina postojećih rehabilitacijskih programa za djecu s ADHD-om koji se provode u odgojno-obrazovnom sustavu nisu učinkoviti jer ne omogućuju djeci generalizaciju ponašanja u promjenjivom, širem socijalnom kontekstu. No, za uspjeh u širem okruženju, važno je poznavati specifičnosti socijalnih i komunikacijskih vještina u djece s ADHD-om, kako bi učitelji mogli djeci pružiti pravovremenu i razvojno primjerenu podršku. Naime, određena istraživanja (Corkum, Corbin i Pike, 2010; Kloo i Kain, 2015; Mikami i Normand, 2015) pokazuju kako djeci s ADHD-om češće nego ostaloj djeci nedostaju primjerene socijalne vještine poput dogovaranja, dijeljenja i uvažavanja sugovornika. Konkretnije, Kloo i Kain (2015) pronalaze kako djeca s ADHD-om prakticiraju pojednostavljene i izravne samo-prezentacijske strategije (poput hvalisanja i nametanja vlastitog mišljenja) zbog čega nisu omiljeni u društvu vršnjaka. Nadalje, Sjöwall i Thorell (2014) navode kako su problemi u vršnjačkim odnosima rezultat nemogućnosti prepoznavanja tuđih emocija i namjera te regulacije vlastitih emocija zbog čega djeca s ADHD-om teško održavaju usmjerenost na vršnjake tijekom interakcije. Iako se čini kako su područja akademskih postignuća i socijalnog funkcioniranja odvojena, Sjöwall i Thorell (2014) ističu kako djeca koja pokazuju simptome ADHD-a, posebice impulzivnost i agresivnost, imaju izražene probleme i u području akademskih postignuća što vide kao rezultat neurobiologijske podloge u smislu zahvaćenosti izvršnih funkcija, kratkog vremena reakcije na vanjske podražaje i neujednačenog općeg emocionalnog funkcioniranja. Drugim riječima, organska podloga ADHD-a u kombinaciji s nepovoljnim socijalnim čimbenicima, rezultira pojavom impulzivnosti i agresivnog ponašanja. Nadalje, Corkum, Corbin i Pike (2010) smatraju da impulzivnost, kao jedan od vodećih simptoma ADHD-a, utječe na verbalne sposobnosti i komunikacijske vještine djece i to na način da su skloni prekidanju tuđih razgovora, nepromišljenosti u razgovoru (nesmotrenosti) i neprepoznavanja tuđih emocija što rezultira konfliktima u interakciji. Što se tiče povezanosti spola i simptoma ADHD-a, Sadek (2013) pronalazi kako dječaci i djevojčice podjednako sudjeluju u vršnjačkom nasilju, s tim da su djevojčice sklonije verbalnom a dječaci fizičkom "razračunavanju" $\mathrm{s}$ vršnjacima. Tu pojavu Gillberg (2014) interpretira u kontekstu socijalnih vještina i komorbiteta. Naime, on tvrdi kako djevojčice posjeduju socijalne vještine u širem obimu od dječaka, te da su socijalno osjetljivije od dječaka a samim tim i manje uključene $u$ vršnjačko nasilje. No, kada su djevojčice počinitelji nasilja, tada češće od dječaka bivaju uključene u programe intervencije i/ili prevencije (ibid.). To znači da se u praksi ADHD u djevojčica lakše identificira zahvaljujući socijalnim normama i očekivanjima (očekuje se da su djevojčice mirne, submisivne). Također, u odnosu na komorbitet, djevojčice su, kako tvrdi Gillberg (2014) sklonije depresivnom ponašanju

2 Važno je reći kako se nasilna i agresivna ponašanja utvrđuju različitim metodama te da ne postoji jedinstveni način kojim bi se to činilo, tj. učestalost i manifestacija nasilnog i agresivnog ponašanja ovise o primjenjenom mjernom instrumentu, metodi statističke obrade i interpretaciji dobivenih podataka. Tako Velki i Kuterovac Jagodić (2012) pronalaze kako je prevalencija agresivnog ponašanja veća onda kada se koristi definicijski pristup, što znači da je prilikom utvrđivanja učestalosti nekog ponašanja potrebno voditi računa o pristupu jer on značajno utječe na interpretaciju dobivenih rezultata. 
i hipoaktvnosti, tj. kod njih dominira nepažnja, a ne impulzivnost, pa su i radi toga manje uključene $u$ vršnjačk nasilje. Posljedično, vršnjaci djecu s ADHDom isključuju te su oni u većem riziku od razvoja ovisnosti i psihičkih poremećaja (depresije) u odrasloj dobi (Barkley, 2015). S obzirom na to da se ADHD može uočiti i u predškolskoj dobi, važno je propitati odnos simptoma ADHD-a i kronološke dobi. Tako Gillberg (2014) tvrdi kako se klinička slika ADHD-a mijenja u odnosu na kronološku dob, pa motorički nemir iz predškolske dobi prerasta $u$ vršnjačko nasilje i impulzivnost u srednjem djetinjstvu i adolescenciji, dok se u odrasloj dobi ADHD očituje kao smanjena podražljivost $\mathrm{i}$ inertnost. Tu pojavu Surman (2013) povezuje s remisijom simptoma jer nakon longitudinalnog praćenja pronalazi kako 50\% odraslih koji su kao djeca imala dijagnosticiran ADHD pokazuje smanjenje impulzivnosti, ali jačanje neorganiziranosti, zamišljenosti ("lutanja misli") i nesamostalnosti. Iako ne navodi razloge takvim rezultatima, može se zaključiti kako bi to moglo biti odraz: (1) medikamentozne terapije praćenih pojedinaca (smanjenje simptoma impulzivnosti i jačanje inertnosti kao posljedica medikamentozne terapije), (2) uključivanja u neki oblik psihoterapije (KBT, realitetna...) tijekom koje su stekli i naučili aktivno primjenjivati određene, konstruktivne i socijalno prihvatljive, strategije nošenja sa stresom te (3) životnog iskustva. No, remisiju simptoma Faraone, Biederman i Mick (2006) ne vide kao odraz akcija okruženja ili želje za promjenom same osobe već ju tumače kao neosjetljivost mjernih instrumenata tj. postojećih dijagnostičkih kriterija koji su uglavnom usmjereni na djecu nižeosnovnoškolske dobi. Zato preporučuju da znanstvena zajednica osmisli primjerene tehnike dijagnostike za odrasle koje bi bile temeljene na longitudinalnim istraživanjima.

Uvidom u literaturu vidljivo je kako je ADHD multidimenzionalni fenomen koji se manifestira tijekom interakcije djeteta i njegova neposredna okruženja, zbog čega je posebno važno da odgojitelji i učitelji mogu prepoznati dijete suspektno na postojanje ADHD-a. Naime, odgojitelji i učitelji u izravnom, kontinuirano radu s djecom i mogu među prvima uočiti ponašanja koja pripadaju ADHD-u. Prepoznavanje djece u riziku za ADHD moglo bi prevenirati vršnjačko odbacivanje i generiranje zatvorenog kruga neza- dovoljstva i vršnjakog nasilja. Stoga pravovremena i razvojno primjerena podrška uključuje kontinuirano praćenje vršnjačkih odnosa a ne samo rad na akademskom postignuću djeteta s ADHD-om ili korekciju ponašanja izvan situacije u kojoj se ono manifestiralo.

\section{CILJ ISTRAŽIVANJA}

Cilj istraživanja bio je provjeriti povezanost različitih simptoma ADHD-a (hiperaktivnost, impulzivnost i nepažnja) dobivenih na temelju dječjih samoprocjena s različitim aspektima vršnjačkog nasilja (tjelesno, verbalno i elektroničko) i agresivnosti (reaktivna i proaktivna agresija) te provjeriti razlikuju li se veličine tih povezanosti za različite simptome kao i spolne i dobne razlike $\mathrm{u}$ navedenim povezanostima.

\section{HIPOTEZE}

H1: Svi samoprocijenjeni simptomi ADHD (impulzivnost, hiperaktivnost i nepažnja) bit će u statistički značajnoj pozitivnoj korelaciji sa svim aspektima vršnjačkog nasilja (tjelesno, verbalno, elektroničko), kao i s obje vrste agresivnosti (reaktivna i proaktivna agresija).

$\mathrm{H} 2$ : Samoprocijenjeni simptomi impulzivnosti pokazivat će statički značajno veću povezanost $\mathrm{s}$ različitim aspektima vršnjačkog nasilja (tjelesno, verbalno, elektroničko) i agresivnosti (reaktivna i proaktivna agresija) od povezanosti samoprocijenjenih simptoma hiperaktivnosti i nepažnje s istim aspektima nasilja i agresivnosti.

H3: Starija djeca, kao i dječaci pokazivat će statički značajno veću povezanost svih samoprocijenjenih simptoma ADHD-a (impulzivnost, hiperaktivnost i nepažnja) s različitim aspektima vršnjačkog nasilja (tjelesno, verbalno, elektroničko) i agresivnosti (rekativna i proaktivna agresija).

\section{METODE RADA}

\section{Sudionici}

U istraživanju su sudjelovali učenici 6 osnovnih škola, iz četvrtih, šestih i osmih razreda na području Brodsko-posavske i Osječko-baranjske županije. 
Ukupno je pristao sudjelovati 501 učenik (odnosno $55,92 \%$ učenika koji su pitani za sudjelovanje), od toga $50,7 \%$ dječaka i $49,3 \%$ djevojčica, prosječne dobi 12,72 godine $(\mathrm{sd}=1,62)$. Prema mjestu stanovanja, 368 sudionika živi u gradu (73,4\%), a 133 u selu (26,6\%). U tablici 1 prikazana je raspodjela učenika po spolu, dobi i razredu koji pohađa.

Tablica 1. Raspodjela učenika po spolu i razredu koji pohađa

\begin{tabular}{|l|c|c|c|c|}
\hline razred & spol & $\mathbf{f}$ & $\mathbf{\%}$ & prosječna dob \\
\hline 4. razred & dječaci & 50 & 48 & $\mathrm{M}=10,9$ \\
& djevojčice & 54 & 52 & $\mathrm{sd}=0,48$ \\
& ukupno & 104 & 20,8 & \\
\hline 6. razred & dječaci & 91 & 49,2 & $\mathrm{M}=12,25$ \\
& djevojčice & 94 & 50,8 & $\mathrm{sd}=0,46$ \\
& ukupno & 185 & 36,9 & \\
\hline 8. razred & dječaci & 112 & 52,6 & $\mathrm{M}=14,32$ \\
& djevojčice & 100 & 47,4 & $\mathrm{sd}=0,49$ \\
& ukupno & 212 & 42,3 & \\
\hline \multirow{2}{*}{ ukupno } & dječaci & 254 & 50,7 & $\mathrm{M}=12,72$ \\
& djevojčice & 247 & 49,3 & $\mathrm{sd}=1,62$ \\
& ukupno & 501 & 100,0 & \\
\hline
\end{tabular}

\section{MJERNI INSTRUMENTI}

\section{RPQ - Upitnik reaktivno-proaktivne agresije}

Agresivno ponašanje mjereno je upitnikom reaktivno-proaktivne agresije (Reactive-Proactive Aggression Questionaire (RPQ; Raine i sur., 2006) koji je namijenjen djeci i adolescentima. Upitnik se sastoji od dvije skale i mjeri reaktivnu i proaktivnu verbalnu i fizičku agresivnost. Skala reaktivne agresivnosti sastoji se od 11 čestica, a Skala proaktivne agresivnosti od 12 čestica. Zadatak sudionika je da za svaku česticu procijene učestalost opisanog ponašanja u određenom vremenskom razdoblju (pri čemu " 0 " znači kako se nikad nisu tako ponašali, ,,1" ponekad su se tako ponašali ili „2" često su se tako ponašali). Ukupni rezultat i rezultat na dvije subskale formira se aritmetičkom sredinom sume odgovora na pojedinim česticama. Pouzdanosti za subskalu reaktivna agresija iznosi Cronbach $\alpha=0,85$, a za subskale proaktivna agresija Cronbach $\alpha=0,90$.

\section{Upitnik o nasilju među školskom djecom (UNŠD; Velki i Kuterovac Jagodić, 2012)}

Upitnik obuhvaća demografske podatke o djetetu (razred, spol, dob, broj članova u kućanstvu, školski uspjeh), pitanja o osjećaju prihvaćenosti i odbačenosti od strane vršnjaka te pitanja vezana uz osjećaj sigurnosti u djetetovu okruženju. Detaljnije su obuhvaćeni podaci o učestalosti doživljenog i počinjenog nasilja prema drugoj djeci. Upitnik je sastavljen od dvije skale, a svaka se skala sastoji od 19 čestica - Skala nasilja među djecom i Skala viktimizacije. Za potrebe ovog istraživanja korištene su Skale nasilja među djecom i pripadajuće subskale (tablica 2). Sudionici istraživanja znakom X trebaju označiti koliko često im se događaju određene stvari u školi (pri čemu ,nikad“ nosi 1 bod, ,rijetko“ (nekoliko puta godišnje) nosi 2 boda, ,ponekad“ (jednom mjesečno) nosi 3 boda, „često“ (nekoliko puta mjesečno) nosi 4 boda te „uvijek“ (skoro svaki dan) nosi 5 bodova. Rezultati dobiveni ovim upitnikom formiraju se na temelju aritmetičkih sredina određenih čestica i teoretski se kreću od 1 do 5.

Tablica 2. Skale i subskale UNŠD-a s pripadajućim brojem čestica i pouzdanosti tipa Cronbach $\alpha$

\begin{tabular}{|c|c|c|}
\hline \multicolumn{3}{|c|}{ Skala nasilja među djecom $(\mathrm{k}=19)$} \\
\hline \multicolumn{2}{|c|}{$\begin{array}{l}\text { Subskala nasilja među djecom u školi } \\
\qquad(\mathrm{k}=13)\end{array}$} & \multirow{2}{*}{$\begin{array}{c}\text { Subskala } \\
\text { elektroničkog } \\
\text { nasilja } \\
(\mathrm{k}=6, \alpha=0,93)\end{array}$} \\
\hline $\begin{array}{c}\text { Subskala } \\
\text { verbalnog nasilja } \\
(\mathrm{k}=6, \alpha=0,85)\end{array}$ & $\begin{array}{c}\text { Subskala } \\
\text { tjelesnog nasilja } \\
(\mathrm{k}=7, \alpha=0,81)\end{array}$ & \\
\hline
\end{tabular}

\section{HIP (Skala hiperaktivnost-impulzivnost- pažnja; Vulić-Prtorić, 2006)}

Skala HIP procjenjuje hiperaktivno i impulzivno ponašanje, te poteškoće u usmjeravanju pažnje. Ukupno se sastoji od 19 čestica, a podijeljena je na tri subskale: hiperaktivnost ( 6 čestica), impulzivnost (4 čestice) i nepažnja ( 9 čestica). Čestice su zapravo tvrdnje kojima su opisani najčešći simptomi hiperaktivnosti, impulzivnosti i nepažnje. Skala HIP konstruirana je na temelju popisa simptoma iz DSM-IV koji se koriste za mjerenje simptoma poremećaja deficita pažnje s hiperaktivnošću i za teorijsko tumačenje simptomatologije ADHD-a. Zadatak sudionika je procijeniti koliko često su im se određena ponašanje javljala tijekom posljednjih 6 mjeseci. U skladu s time, pored svake tvrdnje treba zaokružiti jedan broj: 1 = nikada, 2 = rijetko, 3 = ponekad, 4 = često, $5=$ vrlo često. Rezultat se dobiva aritmetičkom sredinom odabranih česti- 
ca. Pouzdanost za subskalu hiperaktivnosti iznosi Cronbach $\alpha=0,86$, za subskalu impulzivnosti $\alpha=0,80$ te za subskalu pažnje $\alpha=0,88$.

\section{POSTUPAK PRIKUPLJANJA PODATAKA}

S obzirom na to da je za ovo istraživanje bilo potrebno izravno sudjelovanje učenika tj. podatci o ponašanju učenika nisu prikupljani od učitelja i/ili nastavnika već od samih sudionika (djece), posebna pozornost je dana formalnim preduvjetima prikupljanju podataka. U tu svrhu tražene su suglasnosti na tri razine: pismene suglasnosti od ravnatelja, pismene suglasnosti roditelja učenika 4., 6. i 8. razreda i usmene suglasnosti djece pojedinačno (osobno) prije samog anketiranja. Prikupljanje podataka je bilo organizirano prema prethodnom dogovoru s razrednicima i stručnim suradnicima koji su bili prisutni tijekom anketiranja. Dogovorom s učiteljima, razrednicima i stručnim suradnicima se nastojalo što manje ometati nastavne procese u školi. Učenici su anketni upitnik ispunjavali tijekom sata razrednika (grupno) tijekom 45 minuta. Prije same primjene, učenicima je pojašnjena svrha anketiranja, objašnjena su im njihova prava (da sudjeluju/odustanu u bilo kojem trenutku), rečeno im je da je ispitvanje anonimno te im je bila osigurana kontinuirana podrška pri ispunjavanju anketnog upitnika.

\section{REZULTATI}

U tablici 3 prikazani su deskriptivni podaci za sve mjerene varijable. Prikazane varijable dobivene su na temelju aritmetičkih sredina čestica Skale hiperaktivnosti-impulzivnosti-pažnje (HIP), kao i skala i subskala Upitnika reaktivno-proaktivne agresije (RPQ) i Upitnika o nasilju među školskom djecom (UNŠD). Za gotovo sve varijable dobiven je maksimalan raspon odgovora (izuzev varijable nepažnja koja ima gotovo puni raspon). Varijable koje mjere vršnjačko nasilje i agresivno ponašanje imaju blagu asimetričnu negativnu distribuciju (Kolmogorov-Smirnovljev i Shapiro-Wilkov test su statistički značajni), pomjerenu prema nižim vrijednostima odnosno manjoj količini činjenja nasilja i agresije dok varijable hiperaktivnosti, impulzivnost i nepažnje imaju normalnu raspodjelu.

Tablica 3. Prikaz deskriptivnih podataka za mjerene varijable

\begin{tabular}{|l|c|c|c|c|c|}
\hline VARIJABLA & N & Min & Max & M & sd \\
\hline hiperaktivnost & 501 & 1,00 & 5,00 & 2,28 & 1,02 \\
\hline impulzivnost & 500 & 1,00 & 5,00 & 2,15 &, 95 \\
\hline nepažnja & 500 & 1,00 & 4,78 & 2,14 &, 89 \\
\hline verbalno vršnjačko nasilje & 501 & 1,00 & 5,00 & $1,56^{*}$ &, 67 \\
\hline tjelesno vršnjačko nasilje & 501 & 1,00 & 5,00 & $1,27^{*}$ &, 50 \\
\hline $\begin{array}{l}\text { elektroničko vršnjačko } \\
\text { nasilje }\end{array}$ & 501 & 1,00 & 5,00 & $1,10^{*}$ &, 44 \\
\hline $\begin{array}{l}\text { reaktivno agresivno } \\
\text { ponašanje }\end{array}$ & 493 &, 00 & 2,00 &, $64^{*}$ &, 43 \\
\hline $\begin{array}{l}\text { proaktivno agresivno } \\
\text { ponašanje }\end{array}$ & 492 &, 00 & 2,00 &, $18^{*}$ &, 32 \\
\hline
\end{tabular}

* značajan Kolmogorov-Smirnovljev i Shapiro-Wilkov test asimetričnosti distribucije $(\mathrm{p}<, 001)$

Za provjeru povezanost različitih vrsta vršnjačkog nasilja (verbalno, tjelesno i elektroničko vršnjačko nasilje) i agresivnog ponašanja (reaktivna i proaktivna agresivnost) $s$ različitim simptomima ADHD-a (hiperaktivnost, impulzivnost, nepažnja) provedena je korelacijska analiza (izračunati su Pearsonovi koeficijenti korelacije), a značajnost razlika u korelacijama testirana je Fisherovim $\mathrm{z}$ testom (tablica 4).

Tablica 4. Povezanost različitih vrsta vršnjačkog nasilja i agresivnog ponašanja sa simptomima ADHD-a

\begin{tabular}{|c|c|c|c|c|c|c|c|c|}
\hline varijable & 1 & 2 & 3 & 4 & 5 & 6 & 7 & 8 \\
\hline 1. hiperaktivnost & 1 & & & & & & & \\
\hline 2. impulzivnost &, $702 * *$ & 1 & & & & & & \\
\hline 3. nepažnja &, $815^{* *}$ &, $734 * *$ & 1 & & & & & \\
\hline 4. verbalno vršnjačko nasilje &, $289 * *$ &, $411 * *$ &, $304 * *$ & 1 & & & & \\
\hline 5. tjelesno vršnjačko nasilje &, $260 * *$ &, $368 * *$ & ,294** &, $796 * *$ & 1 & & & \\
\hline 6. elektroničko vršnjačkonasilje &, $151 * *$ & $206^{* *}$ & ,190** &, $629 * *$ &, $752 * *$ & 1 & & \\
\hline 7. reaktivna agresija &, $422 * *$ & ,486** &, $406 * *$ &, $472 * *$ &, $359 * *$ &, $248 * *$ & 1 & \\
\hline 8. proaktivna agresija & ,330** &, $459 * *$ &, $318^{* *}$ &, $498 * *$ &, $508 * *$ &, $373 * *$ &, $596 * *$ & 1 \\
\hline
\end{tabular}

$* * \mathrm{p}<0,01 ; * \mathrm{p}<0,05$ 
Dobivene su statistički značajne male do umjerene povezanosti svih mjera agresivnog ponašanja i vršnjačkog nasilja sa svim simptomima ADHD-a. Fisherovim $\mathrm{z}$ testom utvrđene su razlike u značajnosti korelacija između simptoma hiperaktivnosti i impulzivnosti gdje je pronađena statistički značajno veća povezanost simptoma impulzivnosti s verbalnim vršnjačkom nasiljem $(z=2,20, p<0,05)$ i s proaktivnom agresijom $(\mathrm{z}=2,42, \mathrm{p}<0,05) \mathrm{u}$ odnosu na povezanost verbalnog vršnjačkog nasilja i proaktivne agresije sa simptomima hiperaktivnosti. Također su utvrđene $i$ iste razlike u značajnosti korelacija između simptoma nepažnje i impulzivnosti, tj. pronađena je statistički značajno veća povezanost simptoma impulzivnosti s verbalnim vršnjačkim nasiljem $(z=1,95, p<0,05)$ i s proaktivnom agresijom $(\mathrm{z}=2,63, \mathrm{p}<0,01) \mathrm{u}$ odnosu na povezanost verbalnog vršnjačkog nasilja i proaktivne agresije sa simptomima nepažnje. Razlike u značajnosti korelacija između simptoma hiperaktivnosti i pažnje nisu pronađene, odnosno vršnjačko nasilje i agresivno ponašanje podjednako su jako povezane sa simptomima nepažnje i hiperaktivnosti.

Kako su i vršnjačko nasilje i agresivno ponašanje, kao i simptomi ADHD-a u prijašnjim istraživanjima više vezani za muški spol i starije učenike provjerili smo i razlike u povezanosti simptoma ADHD-a i različitih vrsta vršnjačkog nasilja i agresivnog ponašanja s obzirom na spol i razred koji učenik pohađa.

U tablici 5 možemo vidjeti povezanosti vršnjačkog nasilja i agresivnog ponašanja sa simptoma ADHD-a posebno za dječake (iznad dijagonale) i posebno za djevojčice (ispod dijagonale) pri čemu su sve korelacije statistički značajne (izuzev povezanosti elektroničkog vršnjačkog nasilja i hiperaktivnosti za djevojčice koja nije statistički značajna), male do umjerene povezanosti. Fisherovim $\mathrm{z}$ testom utvrđene su dvije spolne razlike u značajnosti korelacija između povezanosti simptoma impulzivnosti i vršnjačkog nasilja te agresivnog ponašanja, gdje su dobivene statistički značajno veće povezanosti između simptoma impulzivnosti $\mathrm{i}$ verbalnog vršnjačkog nasilja za djevojčice $(\mathrm{z}=1,89$, $\mathrm{p}<0,05)$ te simptoma impulzivnosti i reaktivne agresije također za djevojčice $(\mathrm{z}=2,06, \mathrm{p}<0,05)$. Također je dobivena i jedna spolna razlika u značajnosti korelacija između povezanosti simptoma nepažnje i reaktivne agresije gdje je jača povezanost opet dobivena za djevojčice $(\mathrm{z}=2,42, \mathrm{p}<0,01)$.

U tablici 6 možemo vidjeti povezanosti vršnjačkog nasilja i agresivnog ponašanja sa simptoma ADHD-a posebno za 4., 6. i 8. razrede osnovne škole, pri čemu su za 6. i 8. sve korelacije statistički značajne (izuzev povezanosti elektroničkog vršnjačkog nasilja i hiperaktivnosti za 8. razred koja nije statistički značajna), male do umjerene povezanosti, dok su za 4. razrede pronađene male statistički značajne povezanosti, a za elektroničko i tjelesno vršnjačko nasilje nisu utvrđene statistički značajne povezanosti sa simptomima ADHD-a. Fisherovim $\mathrm{z}$ testom utvrđene su dobne razlike u značajnosti korelacija između povezanosti simptoma impulzivnosti i vršnjačkog nasilja te agresivnog ponašanja. Za učenike 6. i 8. razreda dobivena je statistički značajno veća povezanost simptoma impulzivnosti $\mathrm{s}$ tjelesnim vršnjačkim nasiljem (6. razred $\mathrm{z}=2,21$, $\mathrm{p}<0,05 ; 8$. razred $\mathrm{z}=2,82, \mathrm{p}<0,01)$, elektroničkom

Tablica 5. Povezanost različitih vrsta vršnjačkog nasilja i agresivnog ponašanja sa simptomima ADHD-a za dječake (iznad dijagonale, $N=254$ ) odnosno djevojčice (ispod dijagonale, $N=247$ )

\begin{tabular}{|c|c|c|c|c|c|c|c|c|}
\hline varijable & 1 & 2 & 3 & 4 & 5 & 6 & 7 & 8 \\
\hline 1. hiperaktivnost & 1 &, $693 * *$ &, $832 * *$ &, $269 * *$ &, $293 * *$ &, $176 * *$ & $375 * *$ &, $338 * *$ \\
\hline 2. impulzivnost &, $714 * *$ & 1 & ,708** &, $352 * *$ & ,353** & ,216** & ,418** &, $445^{* *}$ \\
\hline 3. nepažnja &, $797 * *$ &, $761 * *$ & 1 &, $277^{* *}$ & ,303** &, $219 * *$ & ,318** &, $293 * *$ \\
\hline 4. verbalno vršnjačko nasilje & ,319** &, $488 * *$ &, $328 * *$ & 1 &, $827 * *$ &, $650 * *$ &, $424 * *$ &, $439 * *$ \\
\hline 5. tjelesno vršnjačko nasilje &, $215 * *$ &, $382 * *$ & ,262** &, $724 * *$ & 1 &, $771 * *$ &, $336 * *$ &, $443 * *$ \\
\hline 6. elektroničko vršnjačko nasilje &, 110 &, $181 * *$ &, $133 *$ &, $582 * *$ &, $705^{* *}$ & 1 &, $212 * *$ &, $334 * *$ \\
\hline 7. reaktivna agresija &, $474 * *$ &, $555 * *$ & ,494** &, $525 * *$ &, $363 * *$ & ,308** & 1 &, $624 * *$ \\
\hline 8. proaktivna agresija & ,378** &, $524 * *$ & ,383** &, $650 * *$ &, $619 * *$ &, $486 * *$ &, $569 * *$ & 1 \\
\hline
\end{tabular}

$* * \mathrm{p}<0,01 ; * \mathrm{p}<0,05$ 
vršnjačkim nasiljem (6. razred $\mathrm{z}=2,66, \mathrm{p}<0,01 ; 8$. razred $\mathrm{z}=2,30, \mathrm{p}<0,05)$ i proaktivnom agresijom $(6$. razred $z=2,13, p<0,05 ; 8$. razred $z=3,15, p<0,01)$ za razliku od učenika 4. razreda osnovne škole gdje su dobivene povezanosti neznačajne ili statistički značajno slabije. Također je dobivena i jedna dodatna statistički značajna razlika između učenika 4. i 8. razreda osnovne škole, gdje učenici 8. razreda pokazuju statistički značajno veću povezanost simptoma impulzivnosti s reaktivnom agresijom $(\mathrm{z}=2,43, \mathrm{p}<0,05)$.

\section{RASPRAVA}

U skladu s prvom istraživačkom hipotezom potvrđena su očekivanja te su dobivene statistički značajne male do umjerene povezanosti svih simptoma ADHD-a sa svim aspektima vršnjačkog nasilja i agresivnog ponašanja (tablica 4). Dobiveni rezultati su u skladu s prijašnjim istraživanjima o povezanosti vršnjačkog nasilja i ADHD-a (Evans i sur., 2015; Barkley, 2015; McQuade i Hoza, 2015). Iako se istraživanjima nastojala potvrditi linearna povezanost uzroka i manifestacije određene pojave, kod ADHD-a se radi o složenom, multidimenzionalnom fenomenu. Ipak, u kontekstu istraživanja agresivnog ponašanja i socio-emocionalnih vještina djece s ADHD-om gdje se pronalazi povezanost ove dvije varijable (McQuade i Hoza, 2015; Mikami i Normand, 2015) može se pretpostaviti kako se u podlozi agresivnog ponašanja i vršnjačkog nasilja nalaze snižene socijalne vještine i emocionalna nesigurnost, koje u kombinaciji s funkcionalno neučinkovitim strategijama komunikacije, u trenutku eskaliraju sukobom. U odnosu na djecu koja su suspektna na postojanje ADHD-a, učestale procjene o problemima u komunikaciji s vršnjacima na razini konflikta, mogu biti indikator koju djecu treba uključiti u preventivne programe jačanja socijalnih vještina i emocionalnog osnaživanja.

Ovim istraživanjem se, također, željelo provjeriti razliku u jačini povezanosti različitih simptoma ADHD-a s vršnjačkim nasiljem i agresivnim ponašanjem. Dobiveni rezultati su očekivani (tablica 4) te je pronađena veća povezanost simptoma impulzivnosti s verbalnim vršnjačkim nasiljem i s proaktivnom agresijom $u$ odnosu na povezanost verbalnog vršnjačkog nasilja i proaktivne agresije sa simptomima hiperaktivnosti i sa simptomima nepažnje, dok za ostale vrste vršnjačkog nasilja i agresivnog ponašanja nije bilo značajnih razlika u povezanosti s različitim simptomima ADHD-a. Prijašnja istraživanja su pokazala kako je u podlozi vršnjačkog nasilja i agresivnog ponašanja zapravo impulzivnost (McQuade i Hoza, 2015; Evans i sur., 2015), tj. nemogućnost samoregulacije tijekom interakcije s okruženjem. Što se tiče oblika vršnjačkog nasilja, verbalno vršnjačko nasilje je najučestalije, najvidljivije i sankcionira se manje od tjelesnog vršnjačkog nasilja zbog čega ga je u širem socijalnom kontekstu primjerenije ispoljiti pa je i povezanost jača. Nadalje, elektroničko vršnjačko nasilje se danas smatra modernim oblikom vršnjačkog nasilja koje postaje sve raširenije zahvaljujući napretku i dostupnosti tehnologije, ali i nemogućnosti pravovremene reakcije okoline da spriječi ili sankcionira takva ponašanja (Barkley i sur., 2015). Odnosno, elektroničko vršnjačko nasilje je odgođeni oblik nasilja, koji nije izravno povezan s impulzivnošću. Elektroničko vršnjačko nasilje češće je odgođena reakcija djeca koja su žrtve vršnjačkog nasilja u realnom svijetu, a putem elektroničkog vršnjačkog nasilja kompenziraju u virtualnom svijetu situacije kad se nisu mogli obraniti u stvarnosti (Erdur-Baker, 2010;

Tablica 6. Povezanost različitih vrsta vršnjačkog nasilja i agresivnog ponašanja sa simptomima ADHD-a za učenike 4., 6. i 8. razreda osnovne škole

\begin{tabular}{|c|c|c|c|c|c|c|c|c|c|}
\hline varijable & hip & imp & ne & hip & imp & ne & hip & imp & ne \\
\hline & \multicolumn{3}{|c|}{ 4. razred } & \multicolumn{3}{|c|}{ 6. razred } & \multicolumn{3}{|c|}{ 8. razred } \\
\hline verbalno vršnjačko nasilje & ,296** &, $315 * *$ & $274 * *$ & ,337** &, $409 * *$ & ,359** & ,280** &, $417 * *$ & $267 * *$ \\
\hline tjelesno vršnjačko nasilje &, 168 & ,092 &, 103 & $276^{* *}$ &, $351 * *$ & ,298** & ,287** & ,409** &, $319 * *$ \\
\hline elektroničko vršnjačko nasilje & , 121 &,- 074 &, 144 & ,242** & $251 * *$ & $282 * *$ &, 130 & ,202** &, $162 *$ \\
\hline reaktivna agresija & ,314** & ,309** & ,317** & ,441** & ,461** & ,429** & $456 * *$ &, $547 * *$ &, $407 * *$ \\
\hline proaktivna agresija & $225 *$ & $230 *$ & $266 * *$ & ,350** & ,438** & ,368** & ,364** &, $528 * *$ &, $310 * *$ \\
\hline
\end{tabular}

** $\mathrm{p}<0.01 ; * \mathrm{p}<0.05$; hip-hiperaktivnost, imp-impulzivnost, ne-nepažnja 
Dehue i sur., 2012). Kod proaktivne agresije i njezine povezanosti sa simptomima ADHD-a radi se o agresivnom ponašanju s postizanjem određenog cilja (Evans i sur. 2015), tj. dijete prakticira proaktivnu agresiju sa svrhom zadovoljenja osobnih potreba i aspiracija. S obzirom na postojanje povezanosti impulzivnosti i proaktivne agresije moguće je reći kako je u osnovi proaktivne agresije negativna emocija ljutnje (što često vodi k impulzivnoj reakciji) iz čega proizlazi postojanje povezanosti. S druge strane, reaktivnu agresiju se češće povezuje sa simptomima i hiperaktivnosti i impulzivnosti (McQuade i Hoza, 2015; Barkley, 2015), kako je dobiveno i u ovom istraživanju. S reaktivnom agresijom podjednako su povezani svi simptomi ADHD-a te su u odnosu na ostale vrste vršnjačkog nasilja i agresivnog ponašanja nađene najviše povezanosti. U osnovi reaktivnog agresivnog ponašanja se nalazi emocija ljutnje i zapravo još uvijek ne postoje jednoznačni rezultati je li agresija uzrok ili posljedica poremećaja deficita pažnje/hiperaktivnosti. Kada se reaktivna agresija tumači u kontekstu sniženih socijalnih vještina, bilo bi dobro provjeriti komunikacijske strategije $\mathrm{i}$ interakcijske obrasce skupina djece u kojima se nalaze djeca s ADHD-om. Naime, zamijećeno je kako provokacija izaziva jaku emociju ljutnje kod one djece koja imaju simptome impulzivnosti. U tom smislu, emocionalna reakcija ljutnje javlja se kao obrambena reakcija organizma na ,neprijateljski“" podražaj. Upravo iz tog razloga, simptomi reaktivne agresije su jače izraženi.

Posljednje se željelo provjeriti spolne i dobne razlike u povezanosti simptoma ADHD-a i različitih aspekata vršnjačkog nasilja i agresivnog ponašanja. Iako neka istraživanja (McQuade i Hoza, 2015; Mikami i Normand, 2015) pokazuju kako nema spolnih razlika u odnosu na vrste vršnjačkog nasilja i ADHD-a, u ovom istraživanju su dobivene spolne razlike i to u suprotnom smjeru od očekivanog (tablica 5). Za djevojčice su dobivene statistički značajno veće povezanosti između simptoma impulzivnosti i verbalnog vršnjačkog nasilja, simptoma impulzivnosti i reaktivnog agresivnog ponašanja te između simptoma nepažnje i reaktivnog agresivnog ponašanja. Ovakvi se rezultati mogu objasniti normativnim vjerovanjima vezanim uz spolne razlike. Kod dječaka se više tolerira impul- zivno ponašanja, a istraživanja su pokazala da oni i jesu češće impulzivni nego djevojčice (Sadek, 2013; Gillberg, 2014). Moguće je zato da se kod impulzivnosti dječaka pažnja pridaje samo kod ekstremnijih odstupanja od normi. Manja količina impulzivnog ponašanja smatra se normalnom (a katkada i poželjnom) razvojnom značajkom dječaka. Za djevojčice prevladavaju drugačija normativna vjerovanja, da su djevojčice tiše i mirnije od dječaka, pa i manje odstupanje od prosječnog impulzivnog ponašanja kod njih može ukazivati na problematična ponašanja kao što su verbalno vršnjačko nasilje i reaktivno agresivno ponašanje. Ispoljavanje verbalnog vršnjačkog nasilja karakterističnije je za djevojčice, za razliku od dječaka koji ispoljavaju više tjelesnog vršnjačkog nasilja (Stassen Berger, 2007; Gillberg, 2014) pa je očekivano da upravo djevojčice koje su impulzivnije pokazuju ovaj oblik neprimjerenog ponašanja, kao i reaktivnu agresiju u čijoj osnovi i je impulzivnost, odnosno nemogućnost kontrole i inhibicije impulsa u situacijama koje se procjenjuju kao prijeteće. Osim toga simptom nepažnje, koji je kod djece s ADHD-om karakterističniji za djevojčice jer češće imaju dijagnozu nepažljivog tipa ADHD (Velki, 2012a), pokazao se jače povezan s reaktivnom agresijom, odnosno sklonošću djevojčica da burno reagiraju u provokativnim situacijama. Odnosno, moguće je da djevojčice zbog deficita pažnje percipiraju i neutralne situacije kao provokativne, usmjeravajući se samo na neke znakove iz okoline (posebice na one koje dožive kao negativne ili prijeteće). Što se tiče dobnih razlika, dobivene razlike u jačini povezanosti su očekivane. Za učenike 6. i 8. razreda dobivena je statistički značajno veća povezanost simptoma impulzivnosti s tjelesnim vršnjačkim nasiljem, elektroničkom vršnjačkim nasiljem i proaktivnom agresijom za razliku od učenika 4. razreda osnovne (tablica 6). Također učenici 8. razreda pokazuju statistički značajno veću povezanost simptoma impulzivnosti s reaktivnom agresijom za razliku od učenika 4. razreda. Očito da je 6. razred ključan, i to iz razloga jer 6. razred predstavlja točku tranzicije u „Zahtjevnije“ razrede, počinje pubertet i otpor socijalnim normama. U prilog tomu govori i Surman (2013) koji ističe 12. godinu života kao prijelomnu za djecu s ADHD-om: klinička slika postaje ustaljena, ponašanja su generalizirana i teže se 
mijenjaju. Također, u odnosu na povezanost proaktivne agresije i ADHD-a i kronološke dobi, važan čimbenik su razvojni procesi, tj. porast djetetovih kognitivnih sposobnosti i generalizacija socijalnih iskustava što rezultira promišljenijim reakcijama, tj. starija djeca promišljenije reagiraju, oni „odabiru“" strategije prema anticipiranim posljedicama. I prethodna istraživanja su pokazala kako postoji porast vršnjačkog nasilja i impulzivnosti s kronološkom dobi (Barkley, 2015; Kloo i Kain, 2015), pa je jača povezanost u ovom istraživanju očekivana. Nadalje, od 6. do 8. razreda vidljiva je tendencija blagog porasta u povezanosti vršnjačkog nasilja i agresivnog ponašanja sa simptomima ADHD-a, da bi u 8. razredu ta povezanost bila stabilna. Krajem osnovne škole vidljiva je najjača povezanosti agresivnog ponašanja i vršnjačkog nasilja s impulzivnim ponašanjem. Prijašnja su istraživanja pokazala kako je vrhunac vršnjačkog nasilja u 8. razredu osnovne škole i prelasku u srednju školu (Olweus, 2010), iza čega slijedi pad pa je i najjača povezanost ovdje očekivana. Tijekom osnovne škole dolazi do porasta agresivnog ponašanja s dobi te najviše agresivnog ponašanja iskazuju djeca u završnim razredima osnovne škole i nižim razredima srednje škole, da bi se prema odraslosti ta ponašanja značajnije rjeđe javljala (Murray-Harvey, Slee i Taki, 2010; Surman, 2013).

Provedeno istraživanje, kao i tumačenje rezultata treba razmotriti s obzirom na neke metodološke nedostatke. Učenici uključeni u istraživanje pripadaju općoj populaciji djece koja nisu prošla liječničku obradu, niti posjeduju dijagnozu, već koja sama procjenjuju da im se određeni simptomi ADHD-a učestalo javljaju. Nadalje odaziv sudionika je bio mali $(55,92 \%)$ bez obzira što je istraživanje je bilo anonimno. Postavlja se pitanje koja djeca, odnosno roditelji nisu pristali da njihovo dijete sudjeluje u istraživanju? Prijašnja su istraživanja pokazala da najčešće roditelji nasilnije djece ne daju pristanak za sudjelovanje djeteta $\mathrm{u}$ istraživanju (Velki, 2012b). Sve varijable u istraživanju ispitane su metodama samoprocjene, stoga postoji mogućnost da su neka djeca namjerno davala krive odgovore ili odgovore za koje smatraju da su socijalno poželjna, a postoji mogućnost da su im neka pitanja bila „dosadna i naporna“ te nisu iskreno odgovorili na njih. Stoga je preporuka za buduća istraživanja usmjeriti se na pridobivanje većeg broja sudionika posebice različite dobi, od predškolske pa do srednjoškolske dobi, te korištenje i drugih mjera, osim samoprocjena (npr. procjene vršnjaka, roditelja, učitelja) kako bi dobili potpuniji uvid u ovu problematiku.

\section{ZAKLJUČAK}

Istraživanje je pokazalo kako postoji povezanost agresivnog ponašanja i vršnjačkog nasilja sa simptomima ADHD-a, i to za sva tri oblika vršnjačkog nasilja (verbalno, tjelesno i elektroničko) i sve tri skupine simptoma ADHD-a (impulzivnost, hiperaktivnost, nepažnja), kao i postojanje povezanosti simptoma ADHD-a s reaktivnom i proaktivnom agresijom. S obzirom na to da je ADHD multidimenzionalni fenomen, $\mathrm{s}$ jakom socijalnom komponentom, odgojno-obrazovni rad s djecom koja imaju ADHD ili u slučaju sumnje na njegovo postojanje, treba obuhvatiti prevencijske aktivnosti jačanja socijalnih vještina. Iako se socijalnim vještinama u odgojno-obrazovnom okruženju ne daje dovoljno pozornosti u smislu preventivnih osnovnoškolskih programa koji bi bili obligatorni na mikro-razini (svaki razred i škola), jasno je kako zaostajanje razvoja ovih vještina može imati nepovoljan učinak u odnosu na djetetovu participaciju u neposrednom okruženju. Kako impulzivnost $i$ agresivnost utječu na kvalitetu odnosa s okolinom, ponajprije roditeljima koji se osjećaju frustrirano i bespomoćno (Barkley, 2015), rehabilitacijski rad i preventivni programi bi trebali obuhvatiti i roditelje, a ne samo dijete. Na taj bi način djeca $\mathrm{s}$ ADHD-om dobila sustavnu, sveobuhvatnu podršku koja im je potrebna za uspješno funkcioniranje $u$ njihovu neposrednom okruženju. 
Tena Velki, Ksenija Romstein: Povezanost samoprocijenjenih simptoma ADHD-a s agresivnim ponašanjem i sudjelovanjem u vršnjačkom...

\section{LITERATURA}

Barkley, R. A. (2015): Emotional dysregulation is a Core Component of ADHD. U: Barkley, R. A. (ur.): AttentionDeficit Hyperactivity Disorder. (str. 122-166.). New York \& London: The Guilford Press.

Corkum, P., Corbin, N. i Pike, M. (2010): Evaluation of a School-Based Social Skills Program for Children With Attention-Deficit/Hyperactivity Disorder. Child \& Family Behavior Therapy, 32, 2, 139-151.

Dehue, F. i sur. (2012): Cyberbullying and traditional bullying in relation to adolescents' perception of parenting. Journal of Cybertherapy \& Rehabilitation, 5, 1, 25-34.

Evans, S. C. i sur. (2015): The Role of Reactive Aggression in the Link Between Hyperactive-Impulsive Behaviors and Peer Rejection in Adolescents. Child Psychiatry \& Human Development, 46, 6, 903-912.

Ercan, E. i sur. (2014): Predicting Agression in Children with ADHD. Child and Adolescent Psychiatry and Mental Health, 8,1,15-25.

Erdur-Baker, O. (2010): Cyberbullying and its correlation to traditional bullying, gender and frequent and risky usage of internet-mediated communication tools. New Media \& Society 12, 1, 109-125.

Faraone S. V., Biederman J. i Mick, E. (2006): The age-dependent decline of attention deficit hyperactivity disorder: a meta-analysis of follow-up studies. Psychol Med, 36, 2, 159-165.

Gillberg, C. (2014): ADHD and Its Many Associated Problems. Oxford: Oxford University Press.

Houck, G. et al. (2012): Self-concept in Children and Adolescents with ADHD. Journal of Pediatric Nursing, 26, 3, 239-247.

Kudek Mirošević, J. i Opić, S. (2011): Handling Students With ADHD Syndrome in Regular Elementary Schools. Napredak, 152, 1, 75-92.

Kloo, D., i Kain, W. (2015): The direct way may not be the best way: Children with ADHD and their understanding of self-presentation in social interactions. European Journal of Developmental Psychology, 6, 1, 1-13.

Loborec, M. i Bouillet, D. (2012): Istraživanje procjena odgojitelja o mogućnosti inkluzije djece s ADHD-om u redovni program dječjih vrtića. Napredak, 153, 1, 21-38.

McQuade, J. D. i Hoza, B. (2015): Peer relationships of Children with ADHD. U: Barkley, R. A. (ur.): AttentionDeficit Hyaperactivity Disorder. (str. 288-305.). New York \& London: The Guilford Press.

Mikami, A. Y. i Normand, S. (2015): The Importance of Social Contextual Factors in Peer Relationships of Children with ADHD. Current Developmental Disorders Report, 2,1,30-37.

Murray-Harvey, R., Slee, P.T. i Taki, M. (2010): Comparative and cross-cultural research on school bullying. U: Jimerson, S. R., Swearer, S. M. i Espelage, D. L. (ur.): Handbook of bullying in schools: An international perspective. (str. 35-47). New York: Taylor \& Francis Group.

Olweus, D. (2010): Understanding and researching bullying: some critical issues. U: Jimerson, S. R., Swearer, S. M. i Espelage; D. L. (ur.): Handbook of bullying in schools: An international perspective. (str. 9-33). New York: Taylor i Francis Group.

Paap, M. C. et al. (2013): The Link between Peer Relations, Prosocial Behavior, and

ODD/ADHD Symptoms in 7-9-Year-Old Children. Posjećeno 12.2.2016. na mrežnoj stranici Hindawi Publishing Corporation: http://www.hindawi.com/journals/psychiatry/2013/319874/

Raine, A. i sur. (2006): The Reactive-Proactive Aggression Questionnaire: Differential Correlates of Reactive and proactive Agression in Adolescent Boys. Aggressive behavior, 32, 1,159-171.

Romstein, K. (2011): Kvalitativni pristup interpretaciji simptoma ADHD-a: implikacije za pedagošku praksu. Život i škola, 57, 26, 101-114.

Sadek, J. (2013): A Clinician's Guide to ADHD. New York: Springer. 
Schwenck, C. et al. (2011): Kognitive und emotionale Empathie bei Kindern und Jugendlichen mit ADHS und Störung des Sozialverhaltens. Zeitschrift für Kinder-und Jugendpsychiatrie und Psychotherapie, 39, 4, 265-276.

Sjöwall, D. i Thorell, L. B. (2014): Functional Impairments in Attention Deficit Hyperactivity Disorder: The Mediating Role of Neuropsychological Functioning. Developmental Neuropsychology, 39, 3,187-204.

Stassen Berger, K. (2007): Update on bullying at school: science forgotten? Developmental Review, 27, 90-126.

Surman, C. B. H. (2013): ADHD in Adults: A Practical Guide to Evaluation and Management. New York: Springer.

Swanson, W. K. (2012): Teacher Knowledge of Attenition Deficit Hyperactivity Disorder Among Middle School Students in South Texas. Research in Middle Level Education, 36, 3, 1-7.

Velki, T. (2012a): Priručnik za rad s hiperaktivnom djecom u školi. Jastrebarsko: Naklada Slap.

Velki, T. (2012b): Provjera ekološkog modela dječjega nasilničkoga ponašanja prema vršnjacima, Doktorski rad, Zagreb: Odsjek za psihologiju Filozofskog fakulteta u Zagrebu.

Velki, T. i Kuterovac Jagodić, G. (2013): Different measurement approaches as sources of differences in data on the prevalence of peer violence, Društvena istraživanja, 23, 2, 259-281.

Vulić-Prtorić, A. (2006): Skala hiperaktivnosti-impulzivnosti-pažnje-HIP. Posjećeno 1. 12. 2015. na mrežnoj stranici Sveučilišta u Zadru: http://www.unizd.hr/Portals/12/Nastavnici/Anita\%20Vuli\%C4\%87-Prtori\%C4\%87/ Znanstveni\%20radovi/58.\%20HIP\%20-\%20opis\%20skale.pdf

Webb, J. T., Goerss, J. i Olenchak, R. (2010): Pogrešne i dvojne dijagnoze darovite djece i odraslih. Zagreb: Weble Commerce.

Žic Ralić, A. i Šifner, E. (2014): Obilježja vršnjačke interakcije i iskustvo vršnjačkog nasilja kojd djece i mladih s ADHD-om. Ljetopis socijalnog rada, 21, 3, 453-484.

\section{THE CORRELATION OF SELF-EVALUATED ADHD SYMPTOMS WITH AGGRESSIVE BEHAVIOR AND PARTICIPATION IN PEER VIOLENCE AMONG CHILDREN IN PRIMARY SCHOOLS}

\footnotetext{
Abstract: Numerous studies have confirmed that ADHD correlates with peer violence and aggression. The main goal of this study was to examine the correlation between different self-evaluated symptoms of ADHD (hyperactivity, impulsivity, and inattention) with different aspects of peer violence (physical, verbal, and electronic), and aggressive behavior (reactive and proactive aggression). Overall, 501 pupils enrolled in grades 4, 6, and 8 of primary school participated in this research, of whom 50.7\% were boys and 49.3 were girls. Their average age was $M=12.72$ ( $\mathrm{sd}=1.62)$. During one class, the pupils completed the Questionnaire on Peer Violence among School Children (Velki \& Kuterovac Jagodić, 2012), the Reactive-Proactive Aggression Questionaire (Raine et al., 2006), and the Hyperactivity-Impulsivity-Inattention scale (Vulić-Prtorić, 2006). A correlation analysis was conducted (Pearson correlation coefficient), while the significance of differences was tested with Fisher's $Z$ test. The analysis showed a statistically significant correlation between all three forms of peer violence-verbal, physical, and electronic-with all three groups of ADHD symptoms, i.e., impulsivity, hyperactivity, and inattention $(r=0.151-0.411, p<0.01)$, as well as with reactive and proactive aggression $(r=0.318-0.486, p<0.01)$. A difference in the significance of correlations, depending on the symptoms of ADHD, has been found in the correlation of verbal peer violence and hyperactivity $(z=2.20, p<0.05)$, versus the correlation to inattention $(z=1.95, p<0.05)$, as well as the strong correlation of impulsivity and proactive aggression versus hyperactivity $(z=2.42, p<0.05)$ and inattention $(z=2.63, p<0.01)$. The differences in the correlations of peer violence and aggressive behavior with the symptoms of inattention and hyperactivity were not found. Results have confirmed previous findings about the correlations of ADHD with peer violence and aggressive behavior, whereas the correlation is especially strong when impulsivity is present. From this research, we can conclude that symptoms of impulsivity represent a risk for developing peer violence and aggressive behavior, and it would be justified to include children who manifest symptoms of impulsivity in programs of peer violence prevention.
}

Keywords: aggressive behavior, peer interaction, peer violence, hyperactivity, impulsivity, inattention 